\title{
A TRIBUTE TO DORA WIEBENSON
}

(1926-2019)

Dora Wiebenson, the distinguished architectural historian, died in New York on 20 August 2019; she had just turned 93 on 29 July. She had outlived most of her friends and colleagues and her name may have faded from collective memory, but her achievement remains intact in our profession. At first she taught at Columbia University, then at the University of Maryland, and finally at the University of Virginia, from which she retired in 1992. She was director of the Society of Architectural Historians between 1974 and 1977. Professor Dora Wiebenson was a pioneer of eighteenthcentury visual studies in America, the focus of her interest being French art and garden design as attested by her magisterial book, The Picturesque Garden in France (1978). It was she who inspired the idea to establish the Historians of Eighteenth-Century Art and Architecture, affiliate group of the American Society for Eighteenth-Century Studies; in 1999 the HECAA's Wiebenson Prize was named in her honour. Her other major books indicate the wider range of her interests, from The Sources of Greek Revival Architecture (1969) to the Architectural Theory and Practice from Alberti to Ledoux (1982).

The reason why she is remembered on these pages is that in her later life she took interest in Hungarian architecture. That is how the book entitled The Architecture of Historic Hungary got published by the prestigious MIT Press 1998, a major effort to popularise Hungarian architecture in the English-speaking world. In all, the book took ten years to complete, and I had the good fortune to be Dora Wiebenson's collaborator in the project and and the volume's co-editor. Subsequently, she turned to the art and architecture of the whole East-Central European region, and in 2001 she launched a journal entitled Centropa. As she pointed out, it was a logical continuation of our Hungarian book. She invited me to be on the advisory panel of the journal, which turned out to be another channel to reach an international audience and promote the cause of Hungarian art and architecture through numerous articles on the subject.

After her death, one of Dora Wiebenson relatives asked me to write my "remembrances" of her, and I gladly complied. Also I thought it might be a good idea to share these memories with the readers of the Acta Historiae Artium, thus paying tribute a fine scholar, who did a remarkable service to Hungarian culture.

First impressions are strong. I remember well when I first met Dora. My professor Anna Zádor (Eötvös Loránd University, Budapest; 1904-1995) called me one day asking me to accompany her fiend, Professor Dora Wiebenson, the internationally acknowledged architectural historian, on a trip to the town of Eger. At the time, in the summer of 1988, there was an important international conference in Budapest on the Enlightenment, which Dora was attending. At Anna Zádor's instructions I called her at the hotel to set a time for our start. I asked her over the phone, "How shall we recognize each other?". "I am tall and look very American", came the answer. And so it was. On our trip (she had hired a car) we were discussing many things, both architecture and politics. Seeing the great buildings of Eger, on our way back, she mentioned 


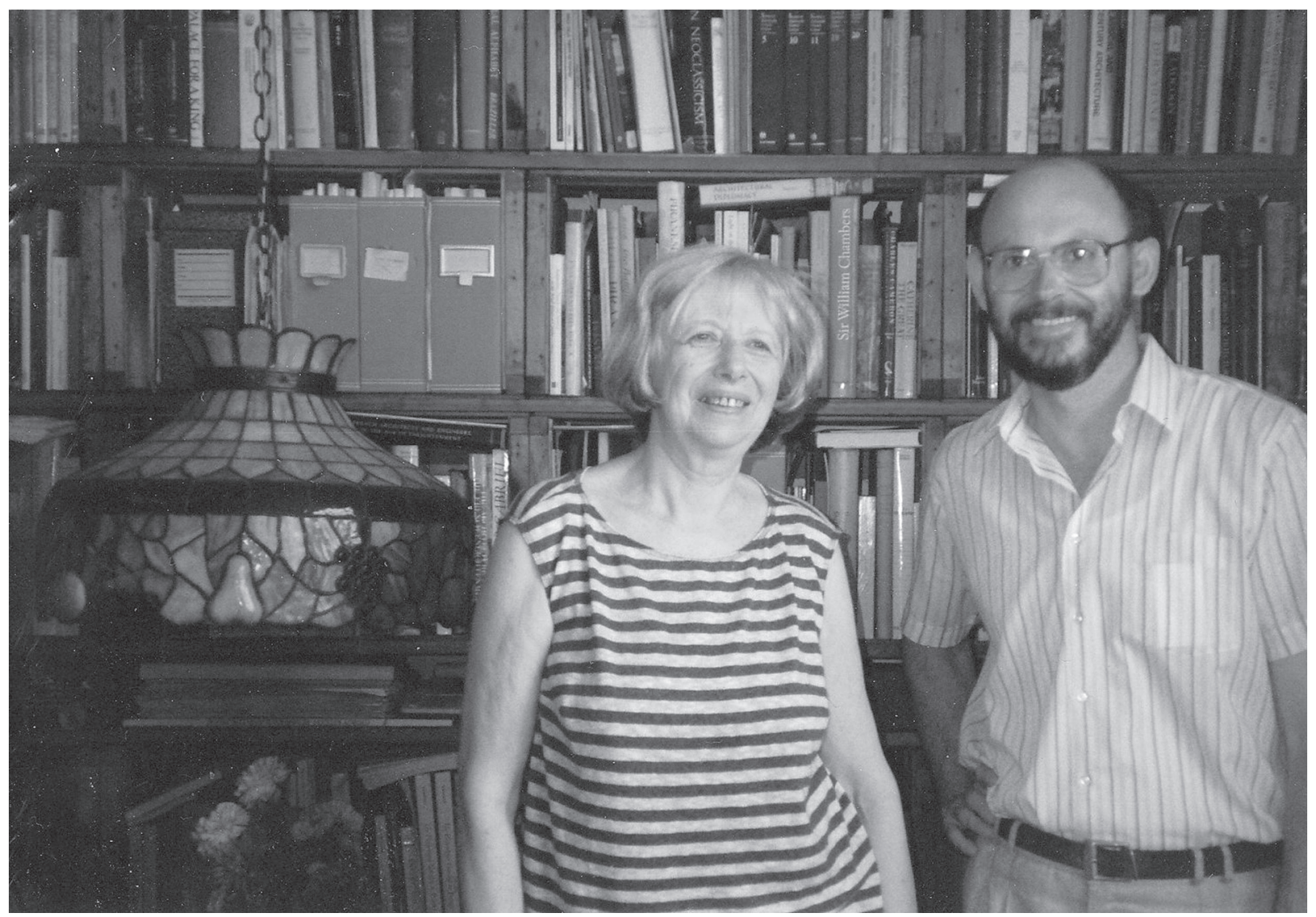

Dora Wiebenson and József Sisa (New York, 1995)

how sad it was that there were no books in English on Hungarian architecture. I told her, "Why don't we write one?" She instantly liked the idea, no doubt realising that it would not be an easy job at all. We still had the iron curtain with all the obstacles involved. In addition, in those times there was no internet, no email, not even fax. So over the next ten years we had to exchange innumerable letters to organise the book, and she came over to Budapest several times to discuss matters with me and our Hungarian co-authors. Each time she was carrying a big bag with all the manuscripts and pictures of our future book. Once I asked her whether she was not afraid of losing it with all its precious contents. "One doesn't even think of it", she answered coolly.

Working with Dora was demanding. She set her well-furnished and well-organised mind to the task and carried on with perseverance. She made the authors work hard and discussed with them not only the general issues but also every detail. For my Hungarian colleagues it turned out be rather exhausting; let it be said in their defence that they also had a foreign language to cope with. Eventually they managed quite well. But Dora's unquestionable authority and towering personality were really needed to bring the project to fruition.

She herself was working hard. She was methodical and seemed to be indefatigable, if not relentless. Not only was she editing the manuscripts and illustrations of seven authors; I remember well that on one occasion, at a rather late stage of the writing of the book, she brought with her a boxful of slips. It turned out that she had prepared in advance the index of the book, each slip containing the name of a place or a person. In other cases, this chore was usually done by assistants at the very end of the project. But Dora thought that the index was an ideal tool to doublecheck the whole text, and of course she turned out to be right. Anyhow, during that stay of hers we were invited to attend a rather strange event in the city of Pécs in southern Hungary. On our way down, which took several hours by train, we were checking the slips against the manuscript, to the obvious amazement and delight of our fellow travellers. In Pécs we attended the inauguration of the bust of one of the martyred generals of the 1848/49 Hungarian revolution. We were standing in a big crowd when a platoon of soldiers pushed their way through the throng, then in 


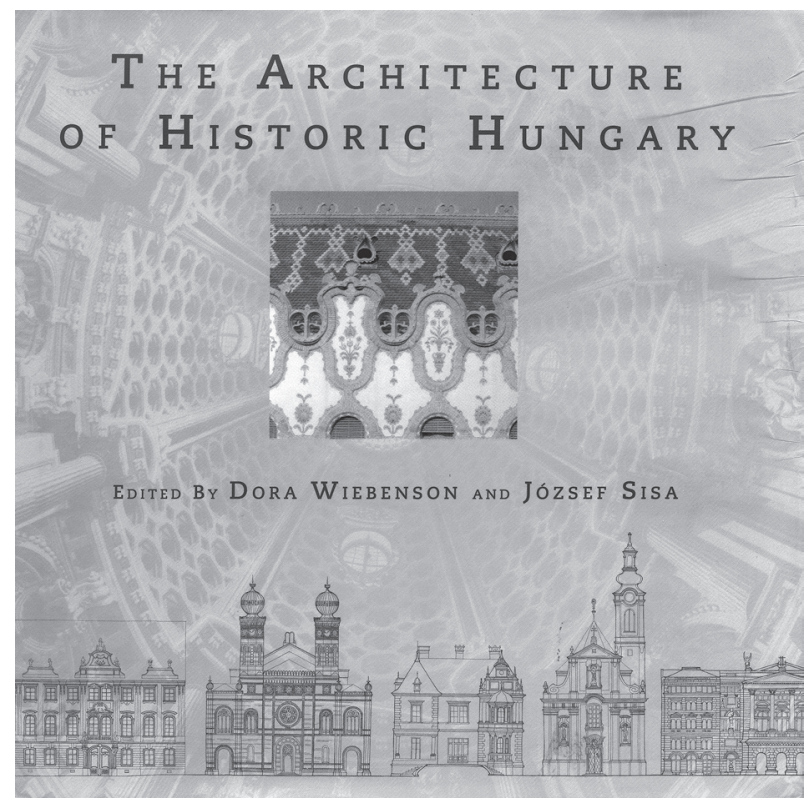

the midst of all the people they took their guns and let loose a deafening volley in the air in honour of the national hero. Happily, unfazed but somewhat dazed, she - we - survived the incident. She even saw the funny side of it.

On another occasion we, along with a student of Dora's, went to Transylvania in my small car (Trabant, the East German contraption). That was still not long after dictator Ceausescu's downfall and execution, and, as could be expected, conditions were quite simple, to say the least. That was true of the roads, the food and the sometimes improvised accommodation. Dora endured all that, including a wasp-bite in a remote village in the middle of nowhere. On our way back we had to wait eight hours at the border, which gave her a taste of the (post-)Communist world. Being disciplined as she was, she always kept her cool.

The book, The Architecture of Historic Hungary, finally came out in 1998 (MIT Press, Cambridge, Mass. - London, England, 1998, 328 pages; its Hungarian version: Magyarország épitészetének története, Vince Kiadó, Budapest, 1998). There were several book-launchings and presentations, some of them here in Budapest, most of them oversees. In order to illustrate the ten years it took to publish it, she liked to point out that when we started the whole project my children were still very young, while now they were teenagers. That was some time indeed, but we did it.

All in all, we are immensely grateful to her for embarking on this Hungarian project. In a way she helped put Hungary on the map of world architecturehistory. And, I am sure she realised that, the timing was perfect - right during and after the fall of the iron curtain, when the former Soviet bloc countries were opening up to the outside world and, temporarily, intense interest turned towards them. I personally learned a great deal from her and from the whole process in terms of how to organise such a big project and, as an editor, how to deal with a bunch of manuscripts by different authors. Later I could apply my skill well in other similar projects. At one point she confided to me that she had never worked with anybody so closely. This was more or less the case the other way round.

While we were still working on the book, I received a grant from the Center for Advanced Study in the Visual Arts (or CASVA, in short), based in Washington, D.C. This gave me the chance to go and see Dora in New York. I know how proud she was of her apartment with the superb view, and how hard she had worked to acquire it. I had the chance then, and later, when my wife joined me, and in the years to come when I visited New York repeatedly, to enjoy her hospitality. I could share her frugal meals and way of life. In fact she opposed waste of any kind and always preferred things economical. When we visited a market not far from her place, she led the way to take small bits from the tasty merchandise on display. She shared her home with two cats, invariably rather big and obtrusive beasts, whom she often chided but could not have lived without. In her later years the cats seemed to take over the whole place. On one of my visits she proudly took me to see the newly completed High Line in western Manhattan. She could not walk that much any longer but she urged me to have a walk, while she settled on a bench.

Her last big project was Centropa, as the subtitle said: a journal of Central European architecture and related arts. She edited and published it for fifteen years, until she was ninety. She spared no effort and expense to launch it, which, considering all that has been said above, was no small sacrifice. Eventually she managed to break it even without outside help. Yet just this personal control gave her the independence in her work which she valued most. It was a daring enterprise: publishing articles on a geographically wide range of countries from the Baltic to the Balkans, approaching cultures with impenetrable languages, locating scholars in a dozen or so obscure countries was an amazing achievement. But finally the journal got off the ground, began to flourish, and found its way to a considerable number of institutions, libraries, places interested in this part of the 
$\operatorname{contr} \rho \rho \cos$

- journal of central european architecture and related arts

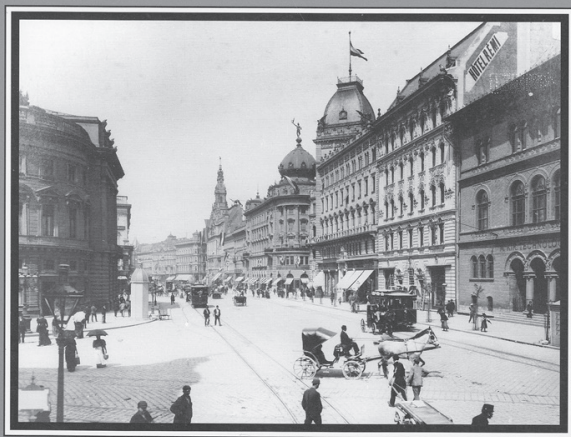

volume 1, number

ianuary 200

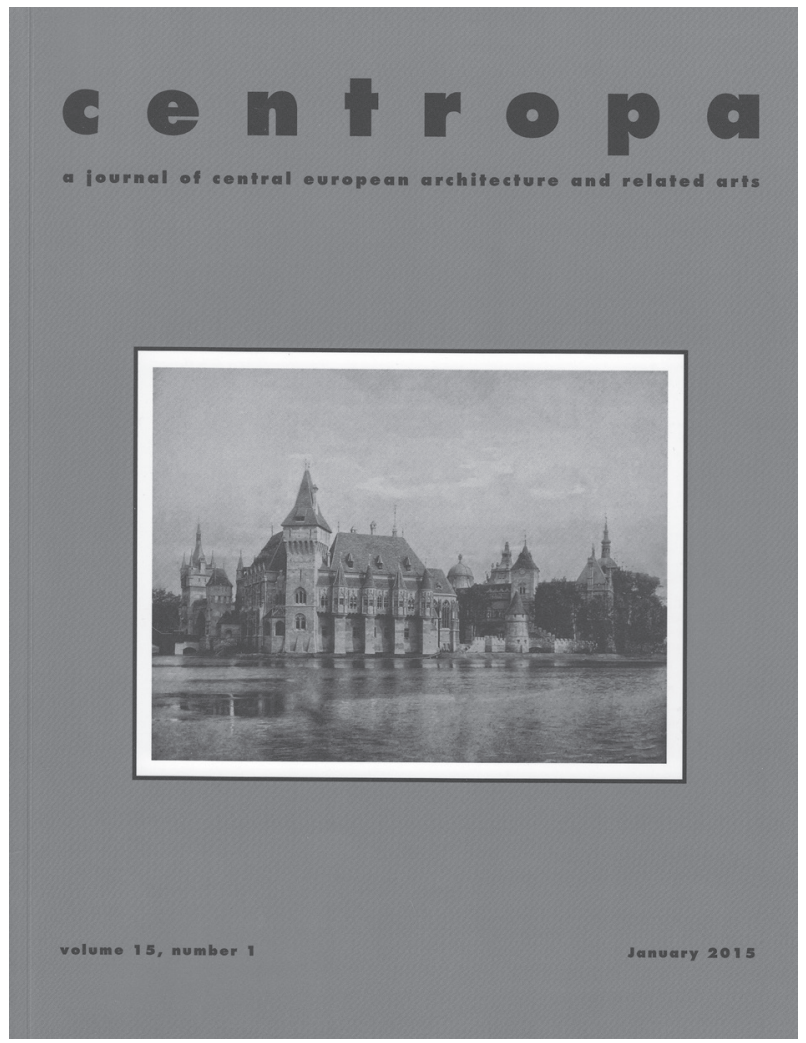

France. And over sixty she could start a "new life", for the benefit of all of us. We will fondly cherish her memory.

József Sisa 